NBER WORKING PAPER SERIES

THE ECONOMICS OF WAGE FLOORS

\author{
Jacob Mincer
}

Working Paper No. 804

\author{
NATIONAL BUREAU OF ECONOMIC RESEARCH \\ 1050 Massachusetts Avenue \\ Cambridge MA 02138 \\ November 1981
}

The research reported here is part of the NBER's research program in Labor Studies. Any opinions expressed are those of the author and not those of the National Bureau of Economic Research. 
This paper contains a theoretical analysis of and summaries of empirical information on consequences of wage floors in the labor market imposed by minimum wages and by labor unions.

Excess supplies are rationed in part probabilistically ("first come, first served"), and in part systematically--by raising hiring standards, or by discrimination and nepotism. Effects on employment, unemployment, and labor force participation, and on wage differentials between the "covered" and the free sector follow. Empirical information on these effects is cited in the minimum wage case, but only wage differentials are analyzed in the union context.

Other consequences outlined here are: lengthening of school attendance, reduction of hours of work, substitution of paid out wages for fringes in the minimum wage case. However, union pressure on fringes is greater than on wages. This strategy produces larger income and greater job security for union members.

The minimum wage reduces opportunities for job training and consequent wage growth. Quits initially decline as wages are pushed up, but turnover is likely to increase as the training content of jobs is reduced. Union wage and fringe advantages reduce quits significantly. However, training as well as wage growth are reduced.

Jacob Mincer Economics Department Columbia University International Affairs Bldg,-Rm. 809 New York, NY 10027

(212) 280-3676 


\title{
The Economics of Wage Floors
}

\author{
Jacob Mincer \\ Columbia University \\ and \\ National Bureau of Economic Research
}

It is often claimed that in a world of "administered" prices and wages, laws of supply and demand are largely abolished. This paper illustrates the contrary proposition that the usefulness and richness of supply-demand analysis is never as apparent as when attempts are made to overrule market forces by decree. The proposition is not novel, but a comprehensive analysis of theoretical and empirical consequences of imposed wages or prices is lacking. An attempt is made here to outline such consequences in the labor market when above-equilibrium wages are imposed by (1) minimum wage legislation, and (2) by labor unions. The analysis represents both a guide and an agenda for empirical work currently under way.

I. Double-crossing the Marshallian Cross

At the basic level of price theory the question is: What are the demand and supply responses to a double-crossing (above the intersection) of the Marhshallian cross?The resulting leftward movement on the demand curve is understood by most freshmen, yet its verification and estimation has kept researchers busy for over three decades. 2 I shall leave the explanation of this perhaps embarassing illustration of our industry to historians of thought or of politics. Be it as it may, it took a long time for the analysis to move from effects on the left side to effects on the right, or supply side of the Marshallian cross.

\footnotetext{
In the labor market.

2In investigaiing effects of minimiam wages.
} 
In the following outline I briefly review the supply effects as well

as demand effects which go beyond the usual focus on disemployment.

\section{(1) Supply Effects}

The standard "double-cross" analysis as described in elementary textbooks is portrayed in Fig. I. It shows a decrease of employment from $E_{O}$ to $E_{m}$ in response to an increase in wages from $w_{0}$ to $w_{m}$. It also shows that the induced excess supply (unemployment) $E_{\mathrm{m}} \mathrm{L}$ is larger than the reduction in employment $E_{\mathrm{O}} E_{\mathrm{m}}$. Note that the alleged expansion of supply from $E_{O}\left(=L_{0}\right)$ to $L$, also implies a tendency for wages to rise in the "free" or non-covered sector.

These conclusions on the supply side are theoretically unwarranted and empirically false. 'The basic reason is that supply responds not only to the wage, but also to the probability of employment. Abstracting from frictional unemployment, the probability of employment is unity in equilibrium, and $S$ is a locus of equilibrium points traced out by shifting $D^{\prime} s$. Since a reduction of vacancies lowers the probability of employment, the quantity of labor supplied will be less than $L$ at $w_{m}$.

The more interesting question, however, is not whether the supply of labor will be less than $L$, but whether it will be increased (to $L_{1}$ ) or decreased (to $L_{2}$ ) from the previous level $L_{O}\left(=E_{O}\right)$.

Wage increases make covered jobs more attractive, but demand for workers in such jobs is reduced, so the probability of finding a job in them is reduced. Thus it is not clear a priori whether labor moves, on balance, toward or away from the covered sector. It can be expected to move out of the covered sector

\footnotetext{
"The "standard" analysis is correct in the case of farm price supports. But this is only because the government stands ready to luy up the surpluses, effectively keeping the probability of sales equal to unity at the higher price.
} 
$2=$

Fia. 1

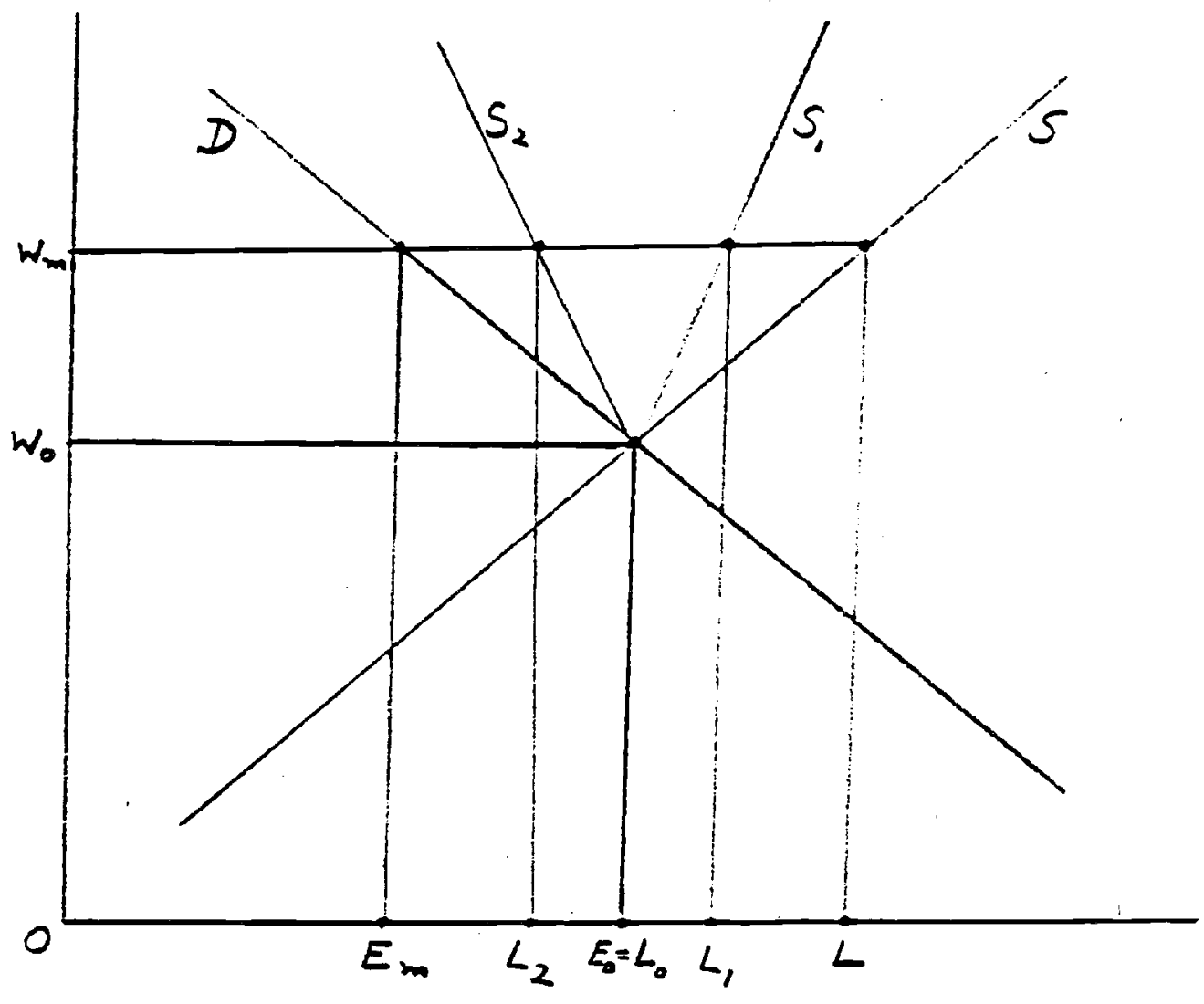


if the probability of employment in it falls by a larger percentage than the increase in the wage (abstracting from risk preferences). Iabor moves into the sector in the opposite case. 1

Outward mobility widens the wage differential between the covered and not-covered labor groups, while mobility toward the covered sector reduces it, but can never eliminate it. onemployment arises in both cases. It. is larger than the reduction in employment when labor is attracted to the covered sector, it is smaller when labor moves out of it.

When the excess supply, resulting from above-equilibrium wages is rationed probabllistically, it can be shown (Mincer, 1976) that outward movement (and reduction in the not-covered wages) occurs when the vacancy rate in the covered sector is smaller than the demand elasticity in it. Empirical work (ibid) indicates that increases:in the minimum wage and in its coverage result in outflows from the covered into the not-covered sector and out of the labor force. Increases in unemployment, attributable to the wage hikes or to increases in coverage are therefore smaller (about $1 / 3$ ) than the decrease in employment.

An interesting implication of the observed supply responses is an increase in the rate of return to further schooling for youngsters at the relevant wage levels (starting wages of high school or less than high school graduates). The observed labor force outflows from the covered sector indicate a deterioration of labor market prospects for job searchers in both sectors. Consequently, the opportunity costs of further schooling declines. That the observed lengthening of school enrollments at the high-school and junior college levels is associated with hikes in minimum wages was shown by Matilla in two recent papers (1978, 1979).

1. Effects of increased costs on relative product prices may mitigate the flows on the labor market, but are not likely to cancel or reverse them. 
It is worth noting that the question of effects of minimum wages on welfare enroliments is, in principle, analogous to the question about effects on school enrollment. A priori, one could argue either way.. Indeed, one of the arguments in favor of minimum wages is that they create an inducement to leave welfare for more attractive paid work. But the evidence on labor force participation and on enroliment effects suggests the opposite, namely that minimum wages induce welfare, not work. ${ }^{1}$

\section{(2) Demand effects}

(a) Job Rationing

In the presence of excess supply, jobs are rationed, at least in part, probabilistically; the reduction in vacancies deters some of the excess supply and creates a queue of job searchers. Beyond that the increase in wages creates incentives for employers to ration jobs by screening out less productive workers so as to reduce the increase in labor costs per efficiency unit, This can be viewed as part of the process of substitution of capital (human or nonhuman) for labor, in response to changes in relative factor prices. Alternatively, or additionally, excess supply also creates opportunities for discrimination and nepotism. Rationing by such changes in hiring standards reduces the unemployment queue and increases the likelihood of outmigration from the covered sector. If rationing involves upgrading of

1. Wachter and Kim (1979) claim that increases in both welfare generosity and minimum wage and coverage levels occurred at about the same time in recent years. The effects appear to reinforce one another, rather than cancel, which, prima facie supports our inference. 
hiring standards, the wage gap between the covered and uncovered sector is overstated by quality components which may be difficult to measure.

The empirical evidence on the nature of job rationing is not clear. The apparent substitution of white students for less educated black youngsters in jobs at the minimum wage level may reflect job rationing by quality or by discrimination. But it may also be due to the fact that a higher wage level or new coverage represents a larger wage increase for blacks than for whites, which results in greater disemployment of blacks.

(b) Disemployment: Numbers or Hours?

Does the reduction in the demand for labor induce primarily a reduction of numbers employed or in hours per worker. This choice is not a matter of indifference to the employer. To the extent that employment costs are unrelated to hours of work and are sizable, exogenous increase in wage rates shift the margin toward reduction of hours per worker rather than arsemployment of workers.

At the level of minimum wages, hiring costs are likely to be small. Training costs may be of some consequence, but as I argue below these are reduced or eliminated as a result of minimum wages. Hours may be reduced in the short run if this process of changing the job content takes a long time (Wessels, 1980). Empirical findings on hours of work are both skimpy and mixed. Zucker (1973), Mixon (1978) and Wessels (1980) find small effects, negative and positive, in low wage industries. Gramlich (1976l finds a rise in part-time work of teenagers, but Matilla (1978) suggests that this finding pertains largely to students.

Isee equation (1) in Part II, section (3), below. 
It may therefore simply reflect the previously reported supply shift from market to school, zather than a response in the relative demand sor hours vs. numbers.

(c) Adjustments in the Wage Package: Fringes, Training and Turnover

If some of the components of the wage package are not subject to wage floors, they will tend to be reduced to offset some of the increase in labor costs. Bere the major items are so called fringe beneftts, largely th the form of pensions and insurance contributions and training expenses of the fism.

The minimum wage applies. only to the paid out money wage. Since wages of the very young and inexpertenced workers are close to the mintmum wage, the effect on tratring ts potantlally the most tmportant consideration under this subrite.

Training expenses of the strm are largely financed by initially lower wages of trainees. Fims bear some of the costs if training protuces worker skills specific to the fl- The minimum wage recuces the scope for workar training in both cases: Even if current productivity of some of the amployed young workers warrants paying the minimum wage, job training is precluded or reduced, since its provision would require paying a subminimum wage.

Thus the labor market difficulties which the minimum wage generates for Low wage young workers are twofold: loss of jobs for some where wages are initially below the minimum and loss of opportunities for training and eareers even for those whose initial productivity is worth as much or somewhat more than the wirimum wage. 
As already noted, minimum wages tend to discourage the formation of "general", that is transferable skills, as well as firm-specific capital, although the effects on the latter may be weaker to the extent that the firm is willing to bear costs of training.

Several types of feedback on the supply side may be expected to result from the barriers to fob training created by minimum wages: Those who are intellectually and financially able to prolong schooling will do so, even if their interests are primarily vocational and they would have preferred job training to staying in school. Thus the prolongation of schooling is due to deterioration of both current job opportunities and of prospects for advancement.

One way speculate that the growth of junior colleges, as well as the growing demand for vocationalisa in college curricula, is partly a reflection of this response. And so is also the growing tendency of students to combine school with market work. ${ }^{1}$ Student work is also partly encouraged by provision of the Fair Labor Standards Act which creates subminimum differentials and exceptions for them. The transition to full-time work at wages above the minimum wage hurdle is made easier by part-period and part-time work while at school. Although jobs of . students are usually low-skilled and casual, they provide some experience and some measure of financial independence. The "dead-end" nature of many of these casual jobs creates no particular anxiety, since they will be left behind as soon as the student has graduated and acquired more rewarding capacities.

1. This is shown to be the case in Mattila's work. There are, of course, additional reasons for this trend which need not concern us here. 
The early labor market difficulties produced by the minimum wage are not easily surmounted by youths who are either unwilling or unable to prolong their schooling. Since opportunities for job training leading to advancement on the job are blocked by the minimm wage for some of them, the young school dropouts must choose jobs with little promise for advancement or become a labor market dropout as well. Non-participation in the labor market, which is induced by the minimum wage, may be financed by the family, by unreported market or illegal activities, or by the welfare system.

The non-students who do not drop out of the labor market despite theif low productivity must contend with several obstacles: greater difficulties (Ionger unemployment in finding jobs in the covered sector, and lesser growth on the job because of the reduced awailability of training on the job. Although it may seem strange to assert that higher wages increase turnover, this can happen in the longer run when minimum wages are raised, if firm-specific training is important in these low-wage jobs; Its elimination reduces the cost of turnover for the worker and for the employer. In the short-run, prior to full adjustment, the effects on tumover are ambiguous, since quits are likely to be reduced and layoffs increased in the covered sector.

We may sumarize these implications of minimum wages as follows; Reduced training on the job leads to reduced pace of job and wage advancement, and to eventually increased turnover in jobs which previously contained specific training opportunities. 
The hypothesis that minimum wages tend to discourage on the job training is largely supported in the empirical aralysis of Mincer and Laighton (NBER Working Paper 441I. Direct effects on reported job training and corollary effects on wage growth were estimated in longitudinal microdata of the NLS and RSID covering the period 1967-1971 in the NIS and 1973-1975 in the PSID. The effects. were consistantly negative and stronger at lower education levels. No effects were observed in groups when education exceeds high school. The effects on turnover were mixed. It decreased among young NLS whites, and increased among NLS blacks and PSID whites. Whether these apparentiy conflicting findings on turnover reflect a distinction between short and long-run adjustments remains unclear. 1

Our procedure relied on differences in wage levels across states for the "same worker" (as estimated by. wage functions.) and on differences in coverage among whites to construct the minimum wage variables. Alternative methodologies used by M. Hashimoto (1980) produced qualitatively similar results on the wage growth question.

${ }^{1}$ Mixon (1978) found that minimum wages reduce quits in manufacturing industries in the short run. 
II. The Minimum Wage Model as a Guide to Union Wage Effects

\section{(1) Supply Responses}

In contrast to the minimum wage literature the union effects literature tends to focus on union-nonunion $(n-u)$ wage differentials rather tha $n$ on employment effects, and even less on unemployment and labor mobility consequences. Does labor move out of the unionized sector thereby reducing nonunion wages or the opposite? If mobility is out of the sector the measure of union wage gain is biased upward, if into the sector it is biased downward. ' The hypothesis one encounters more frequently in the union literature is that the wage gap is an underestimate of union wage gains because of the so-called threat effect. The notion is that in response to increases in union wage rates nonunion firms raise their wages in order to reduce the probability that a union will organize their employees. This kind of behavior, if true--and the evidence is not clear, needs to be distinguished from supply effects.

However, if, as both theory and empirical analyses suggest (Mincer, 1981), the union wage push leads to selective rather than probabilistic rationing of jobs, by upgrading of hiring standards or by nepotism and discrimination. labor moves to the non-union sector in all cases. Consequently, unless offset by threat effects, wages are reduced the non-union sector, but with the elimination of queues little unemployment would be observed in the covered sector.

Empirical studies of the effects of unions on non-union wages ${ }^{2}$ show mixed or negligible results. This suggests that either supply effects are largely offset by threat effects, or that the non-union sector is too large relative to the union sector ( $80 \%$ of labor is not unionized in the U.S.) to show any discernible supply effects.

IFor a thorough discussion of the difference between wage gain and wage gap, see Lewis (1963). 2 Freeman and Medoff (1978), Donsimoni and Shakotko (1979), Kahn (1980). 
The traditional use of the coverage variable ( $\%$ unionized) alone can be misleading. Its interpretation as a measure of union power to raise wages need not be correct, if supply effects matter. For example, assume that union wage gains are uncorrelated with coverage, but increased coverage results in outward mobility. Then larger coverage would be associated with larger u-n wage gaps, but the interpretation that coverage measures union power to raise wages would be incorrect.

(2) The Wage Push and Hiring Standards

In contrast to legislatively imposed minimum wages, union wage gains are endogenous to union power, objectives, and conditions. Their size is not easy to determine. This has been a subject of extensive research in the past two decades. Much of it relies on estimating wage differences between union and nonunion labor of otherwise similar quality. Since full standardization is never possible, the estimates are subject to debate. Available longitudinal data permit a "before and after" analysis carried out on the same individuals. The same analysis permits estimates of selectivity into union job hiring, since information on prior wages and training is available.

Current work with longitudinal micro-data ${ }^{2}$ indicate that the one or two-year wage gain of men who move from non-union to union membership 2 Mellow (1981), Mincer (1981). 
significantly exceeds the wage change of others whose tenure or mobility status (inter-firm or inter-industry) is the same. This gain estimated between a third to two-thirds of the (standardized) wage differential in the cross-section. ${ }^{1}$ The latter averages about $20 \%$. The remainder can be viewed as an indirect estimate of the quality adjustment in hiring. More directly, the fact of selectivity in hiring is seen in the higher non-union wage (òn the previous job) of new union hires compared to non-union hires (Mincer, 1981 ). The differential between these prior wages is an estimate of the selectivity component in the cross-sectional union-nonunion wage differential.

\section{(3) Effects on Hours of Work}

If numbers employed $(N)$ and hours per worker (H) are viewed as separate factors of production, cost minimizing employers will determine their demand for $\mathrm{N}$ and $\mathrm{H}$ at the point where the ratio of marginal factor costs is equal to the ratio of marginal productivities, i.e., the slope of the optimal production isoquant.

Following Rosen (196\%), the equilibrium marginal factor cost ratio is: ${ }^{2}$

$$
\frac{M C_{N}}{M C_{H}}=\frac{H}{N}+\frac{F(r+q)}{N W}
$$

where $F$ is the fixed cost of employment per worker, amortized per period by $r$, the interest cost of capital and by $q$, the worker quit probability which depreciates the capital sum creating a capital loss Fq per period.

To the extent that $F$ is sizable, an increase in the wage rate $w$ reduces the factor cost ratio shifting the relative demand away from hours toward numbers. In the minimum wage case we argued that $F$ is significant at most in terms of training expenses, but that minimum wages tend to reduce or eliminate such

\footnotetext{
${ }^{1}$ A similar approach by Mellow (1981) applied to a large CPS two-year panel showed somewhat smaller union gains. Mellow's data, however, did not permit analyses by

${ }^{2}$ Let total labor costs be $C=N H W+N F(r+q)$, Then $M_{n}=\frac{d c}{d n}=H W+F(r+q)$ and $M C_{H}=\frac{d c}{d h}=N W$
} 
expenses, so that the predicted effects on hours may be observed only in the short run before the adjustment is completed, or it may be indeterminate.

In the union case, union pressure on wages extends to most components of the wage package. Indeed, union push on components other than directly paid out wages appear to be even strongen. Union fringe benefits exceed non-union benefits not only in dollar value but also as a proportion of the wage package (about 30\%). A number of possible explanations have been conjectured, running from union democracy which favors the older worker to union management of pension funds as an instrument of power. One economic argument relies on reduced turnover, which is a result of union wage push and of other gains. In the presence of incomplete vesting of pensions in the worker, longer tenure - of union members means that the probability of ultimately receiving the pension is higher in union than in non-union jobs. Hence the incentive to push for larger pensions (Freeman, 1978). But why increase fringe benefits by a larger percentage than the increase in the paid out wage? One reason is the higher marginal income tax rate, if the income elasticity of worker demand for fringes is otherwise unitary (Rice (1966). But this explains only a small part of the proportional increase (Donsimoni and Shakotko, 1979). The analysis of effects of wage push on hours may provide a sufficient rationale: An increase in union wages $W$, with $F$ unchanged, would lower the ratio of marginal factor costs both by raising the denominator in the second right hand component of equation ( 1 ) and by reducing $q$ in its numerator. If hours are reduced, weekly earnings may not increase much even if wage rates 
rise significantly. To blunt the adverse effect on hours, more specifically, to prevent their reduction which would limit union gains in earnings, costs (F) such as fringes which are partly unrelated to hours, must be increased by a larger percentage than the paid out wage, $(w)$ since quit rates $(q)$ decline. Our evidence that union hours of work are not significantly shorter than hours of (comparable) nonunion workers at least does not contradict this analysis. In contrast to hypotheses which rely on non-wage aspects of unionism to explain the larger ratio of fringe benefits to paid out wages in union employment, this analysis predicts a positive link between the percent union wage premium and the relative increase in fringe benefits (F). Moreover, the percent increase in $F$ is expected to exceed the percent increase in the wage, since the larger the latter, the bigger is the decrease in the quit rate. Thus unions which achieve the biggest gain in paid out wages would also want the largest proportion of their total compensation in fringe benefits.

An important consequence of higher sixed costs (in hiring and in fringes) imposed on union employers is greater stability of employment -- reduced Eluctuations in $\mathrm{N}$, when labor demand fluctuates (see Rosen, 1968). As a result, the major means of adjustment to fluctuating demand in union employment are the use of overtime when labor is short and the use of temoorary layoffs (recall unemployment) in slack times. Temporary layoff is favored by union workers, as it implies lesser income loss than corresponding reductions in weekly hours, because of unemployment compensation and other unemployment benefits. For their part, employers can expect less attrition, since temporaily laid off union workers are less likely to look for other jobs than comparable non-union workers. 
The evidence that average weekly hours are not less in the union than non-union sector, that overtime is more prominent and that temporary layoffs are more frequent and a larger proportion of total layoffs in the union sector is available ${ }^{1}$, but needs to be investigated more rigorously.

(4) Wage Profiles, Turnover, and Training

Wage profiles of union members are higher and quit rates lower than in non-union jobs. These facts are neither unrelated nor surprising. Since the wage received in union employment exceeds the worker's opportunity wage in non-union employment, and fringes even more so, he is less likely to quit a union job then a non-union job. Quit rates in the union sector are about half as large as in the non-union sector. The differences are smaller for separations, since layoffs (much of which are recall) are larger, in the union sector--also an implication of larger fixed labor costs, as already observed.

Lower quit rates of union workers have been ascribed to the existence of grievance procedures ("voice" instead of "exit"). ${ }^{2}$ Although union wage premia are assumed to play a part in the reduction of mobility, no direct empirical tests have been offered. Longitudinal micro-data permit direct tests: If unionization reduces job mobility, this reduction should be observed on the same individual by comparing his mobility before and after joining a union firm. And if the wage premium gained by moving to a union firm matters, the reduction in mobility should be greater the greater the wage gain. Tests carried out on NLS and PSID panels (Mincer, 1981) confirm these predictions, but they leave out advantages in fringes which are not available in the data.

${ }^{1}$ In MID, straight-time in weekly hours are about $4 \%$ shorter in union jobs, but total hours are no less in union than in nonunion jobs. See also Blau and Kahn (1981), and Raisian (1981).

2

See Freeman (1980). But there is little reason to believe that similarly effective procedures cannot be adopted in non-union firms, given the incentives to reduce turnover costs. 
Analyses of minimum wages (Mincer and Leighton, 1980) showed mixed effects on turnover. Since minimum wages apply only to the paid out money component, other components of labor costs are likely to be reduced, and this is apparently true of training costs whether they are borne by employers or employees. Although the initial increase in wages is likely to reduce quits, later dilution of job training content may well increase turnover.

Although the typical union wage profile is higher in level, it is flatter than the typical non-union profile. This difference has been found in many studies and has been ascribed to union policy of compressing wage differentials across firms and workers. The policy of wage compression has been attributed to union pursuit of equity, to administrative convenience in collective bargaining, and to union efforts to reduce competition from lower wage firms. In studies of minimum wages flatter wage growth has been conjectured and observed, and inferred to be a consequence of increased wage costs replacing job training expenditures. Union effects on job training are more complex: They may be derived from union wage pressures on the entire tenure profile of wages: Explicit and rigid rules make seniority a necessary condition for promotion in most union firms, and wage progressions are adhered to, though they may be slowed or accelerated, along seniority lines. Such provisions limit the supply of trained workers from other firms, and reduce incentives for general (transferable): training.

Although specific training need not be affected, since employers can rely on lesser quit and employees on job security afforded by seniority, general (transferable) training is likely to be reduced. Empirical wage functions which distinguishes between effects of work experience at fixed levels of tenure, and of length of tenure at given levels of experience, show little difference in the slopes of tenure profiles of wages between union and 
and non-union workers, but a much flatter union experience profile. Although volumes of specific training need not be affected, direct responses in the micro-data confirm that total training is less frequent in union firms. 


\section{References}

O. Ashenfelter and G. Johnson, "Unionism, Relative Wages, and Labor Quality," American Economic Review, October, 1972.

F.D. Blau and I.M. Kahn,"The Exit-Voice Tradeoff in the Labor Market: Some Additional Evidence." (Mimeograph, 1981).

M.P. Donsimoni and R. Shakotko, "Unionism and the Structure of Total Compensation," Discussion Paper 21, Columbia University, August; 1979.

G.J. Duncan and F.P. Stafford, "Do Union Members Receive Compensating Wage Differentials," American Economic Review, June 1980.

R. Freeman, "The Effects of Trade Unionism on Fringe Benefits," NBER Working Paper No. 292, October 1978.

, and J. Medoff, "The Percent Organized Wage Relationship," NBER Working Paper No. 305, December 1978.

E. Gramlich, "Impact of Minimum Wages on Other Wages, Employment, and Family Incomes," Brookings Paper 1, 1976.

M.Hashimoto, "Minimum Wages and Earnings Growth of Young Men," Econometric Society Meetings, December 1979.

L.M.Kahn, "Union Spillover Effecrs on Unorganized Labor Markets," Journal of Human Resources, Winter 1980. H.G. Lewis, Unionism and Relative Wages in the U.S., Chicago University Press,
1963.

J.P. Mattila, "Youth Labor Markets, Enrollments and Minimum Wages," Industrial Relations Research Association Proceedings, 1978. , "The Impact of Minimum Wages on Teenage Schooling," AEI Conference, 1979.

W. Mellow, "Unionism and Wages: A Longitudinal Analysis," The Review of Economics and Statistics, February 1981.

J. Mincer, "Unemployment Effects of Minimum Wages," Journal of Political Economy, Part 2, August 1976.

, and L. Leighton, "Effects of Minimum Wages on Human Capital Formation," NBER Working Paper No. 441, February 1980.

J. W. Mixon, Jr., "The Minimum Wage and Voluntary Labor Mobility," Industrial and Labor Relations Review, October 1978. C.J. Parsley, "Labor Unions and Wages: A Survey," Journal of Economic Literature,
March 1980 .

J. Raisian, "Contracts, Tenure, and Cyclical Variability in Wages and Hours," (BLS Mimeograph, April, 1981).

A. Rees, The Economics of Trade Unions, 2nd. ed., Chicago University Press, 1977. A. Rice, "Skill, Earnings, and the Growth of Wage Supplements," American Economic
Review, May 1966 . 
S. Rosen, "Trade Union Power, Thrust Effects, and the Extent of Organization," Review of Economic Studies, April 1969. July 1968.

"Short-run Employment Variation on U.S. Railroads," Econometrica,

G.J. Stigler, "The Economics of Minimum Wage Legislation," American Economic Review, June 1946.

M.Wachter and S. Kim, "Time Series Changes in Youth Hoblessness," NBER Working Paper No. 384, August 1979.

F. Welsh, "Minimum Wage Legislation in the U.S.," Economic Inquiry, Spetmeber 1974.

W. Wessels, "The Effects of Minimum Wages in the Presence of Fringe Benefits," Economic Inquiry, May 2980.

A. Zurker, "Minimum Wages and the Demand for Low Wage Labor," Quaterly Journal of Economics, May 1973. 